\title{
De corpo presente na dança digital distribuída em rede
}

Ivani Santana

PPGAC e IHAC-UFBA/CNPQ

Esse texto trata da Dança Telemática como uma configuração pertinente à Cultura Digital não apenas pela popularização da Internet na década de 1990, mas por ser um meio com especificidades que vão de encontro aos interesses de muitos criadores que já se dedicavam a relação arte-ciência-tecnologia. Tais desejos ganharam novas possibilidades com o crescimento, a amplitude e o acesso às redes avançadas de telecomunicação, estabelecendo assim um novo locus de atuação para os artistas.

Esse artigo considera dois desafios principais da Arte em Rede: (a) como configurar uma obra distribuída e por meio de uma tecnologia com aspectos específicos; e (b) qual a relação entre os agentes (artistas e público) em um contexto que impõe novos entendimentos sobre espaço-tempo, distância e presença. Três premissas fundamentam essa reflexão: (1) o processo criativo como uma trajetória do artista e não apenas da concepção de uma obra (Salles, 2008), aspecto assumido neste texto como um testemunho da produção de conhecimento na Arte; (2) o corpo na Cultura Digital como embodied (Hansen, 2006), conceito que contesta o entendimento do "pós-humano" e da desmaterialização do sujeito; e (3) a configuração artística como um artefato cognitivo (Clark, 2003). Tais premissas demonstram que as formulações artísticas dos criadores estão implicadas na forma como o sujeito apreende o meio que habita.

Apesar da Arte Postal ser considerada um início, foram as novas tecnologias da comunicação (Internet) que promoveram uma grande mudança na "arte da 
distância". Enquanto a primeira precisava de um "corpo" físico para ser transportado, na era telemática essa corporalidade ganha outros contornos e apresenta-se de outras formas que não mais pela sua materialidade física. Tal aspecto já era possível desde a invenção das ondas eletromagnéticas de Heinrich Hertz no século XIX. Naquele momento, o "trânsito" entre as coisas do mundo sofreu uma alteração sem precedentes e que modificou a noção de espaçotempo, distância e presença, temas de interesse desse artigo. "Depois dessa descoberta não é mais o corpo ou o objeto material que devem viajar para comunicar a informação, mas são as ondas imateriais e invisíveis transportando sinais de um ponto ao outro, de uma estação a outra" (Baumgärtel, 2005, p. 61).

O termo telemática ${ }^{1}$ (télématique) criado por Alain Minc e Simon Nora refere-se a visualização de dados armazenados no computador através de redes de telecomunicação. Outras definições assumem a conjunção do prefixo "tele" como distante (ex.: telescópio, telefone) - e "mática" como relacionado à informática. O estudioso Vilém Flusser compartilha parcialmente dessa definição e acrescenta a noção de autômato - automovimento - para o sufixo "mática", compreendendo telemática como uma técnica de aproximação automática do distante, um processo que, por meio de aparatos tecnológicos, permite aproximar as pessoas distantes entre si, no espaço e no tempo, para que possam realizar-se mutuamente (Flusser, 1998).

O grifo acima endossa o interesse dos trabalhos analisados nesse artigo em efetivar uma relação mútua e convergente levando em consideração a natureza própria das redes avançadas de telecomunicação. É importante também considerar que alguns artistas, principalmente no campo da música, preferem o termo Networked Performance e compreendem telemática como um termo que não carrega preocupações artísticas, pois estaria mais relacionado com o trânsito da informação computacional em si, não enfatizando a questão da cooperação entre pontos distribuídos. Para aqueles artistas, o foco não estaria tanto na questão da distância, mas na conectividade, no aspecto metafórico de "rede" que se efetiva quando as tecnologias de telecomunicação interligam vários pontos

\footnotetext{
${ }^{1}$ No inglês é comum encontrarmos os termos correlatos a telemática tais como: mobile computing (computação móvel), ubiquitous computing ou pervasive computing (computação ubíqua).
} 
(não necessariamente distantes). Schroeder e Rebelo (2009) fazem uma reflexão sobre essa questão e afirmam que historicamente o termo foi utilizado em 1560 em uma analogia sobre a rede de pesca como uma ferramenta para o trabalho. Os autores esclarecem ainda que o matemático Euler (1707 - 1783) teria sido o primeiro a descrever a rede demonstrando as propriedades dos vértices (nós) e arcos (rotas) como uma ferramenta para conectividade.

Nesse artigo, serão utilizadas as duas referências: telemática e arte em rede, uma vez que o objetivo das pesquisas e criações analisadas nesse texto está voltado tanto para a questão da informação (digitalização e processamento) do corpo do artista (do dançarino, do músico, ou da música, de agentes autômatos, e do próprio público), bem como a distância e a conectividade entre os pontos remotos. A "realização mútua" (Flusser, 1998) talvez seja a melhor forma de definir o interesse das pesquisas aqui abordadas, pois quando os corpos são multiplicados, desdobrados, projetados em outros espaços mantendo o diálogo com o outro, o intuito é propiciar ao dançarino ${ }^{2}$ uma efetiva atuação, ou seja, uma "realização" com o parceiro localizado em outro tempo e espaço. Aqui a "realização mútua" é considerada possível por haver uma compreensão do "embodiment de presenças estendidas", conforme será explicado ao longo desse texto.

Como uma breve contextualização, podemos citar o experimento Satellite Arts (1977) de Kit Galloway e Sherry Rabinowitz. As imagens dos dançarinos situados em Maryland e de seus parceiros localizados na Califórnia foram transmitidas e mixadas em tempo real. Em 1986, David Rockeby realizou um projeto no qual enviava e recebia as sensações dos movimentos de dançarinos que estavam localizados em Toronto e em Paris através de diferentes dispositivos (telefone, vídeo, computador, etc.). Em setembro de 1990 foi realizado o Eletronic Cafe Internacional com performances e danças utilizando videofone, fax, slow scan entre várias cidades (Prado, 2003). Outro exemplo importante é a instalação Telematic Dreaming (1994), de Paul Serman, com performance de Susan Kozel, em Amsterdam. Kozel em seu livro Closer: performance, technologies, phenomenology (2007), discute as relações de (tele)presença que sentiu do

\footnotetext{
2 O termo bailarino vincula-se ao profissional que atua em configurações do balé, por essa razão, tratando-se da dança contemporânea em campos interdisciplinares, o termo dançarino é mais coerente. De acordo com as fundamentações teóricas assumidas nesse artigo, uma configuração artística está implicada com um pensamento e entendimento de mundo, consequentemente, com um posicionamento político; por essa razão a distinção aqui assumida entre bailarino e dançarino.
} 
público durante as quatro semanas da instalação, quando permaneceu interagindo com o público. As sensações que apreendeu no seu corpo por meio do contato telemático foram de poesia, cuidado e atenção, mas também de dor, violência, sensualidade, sexualidade e agressividade demonstrando que o corpo também sofre e sente através da telepresença.

As considerações desse artigo refletem os resultados da minha investigação teórico-prática no campo da dança telemática iniciada nos Estados Unidos em 2001, quando criei DRYWET, uma performance artística entre dois pontos geográficos localizados no campus da Ohio State University (OSU). ${ }^{3}$ No Brasil, apenas em 2005 foi possível dar continuidade às minhas investigações nesse campo, quando a Rede Nacional de Ensino e Pesquisa (RNP) me convidou para criar um espetáculo de dança telemática como lançamento da Rede Ipê. ${ }^{4}$

Analisando a minha trajetória anterior, percebo que o conhecimento adquirido com os processos criativos de dança com mediação tecnológica foi determinante para minhas criações em telemática. Portanto, a telemática foi um caminho natural para continuar minhas investigações sobre aspectos relacionados à corporalidade do dançarino quanto à sua percepção sensório-motora em ambientes mediados tecnologicamente. ${ }^{5}$ Esses aspectos são aqui considerados como a produção de conhecimento de um conjunto de processos criativos ao longo de um percurso que venho desenvolvendo desde a década de 1990 na articulação arte-ciência-tecnologia. Tal conhecimento foi construído durante as diversas criações, dos vários experimentos, tanto aqueles que foram levados à

\footnotetext{
3 Convidada em 2001 pelo professor Johannes Birringer como artista residente no Environments Lab - Departamento de Dança (Ohio State University, Estados Unidos), na época coordenado por ele, meu foco principal de pesquisa era o processo de digitalização do movimento (Motion Capture), o qual realizei no Advanced Computing Center for the Arts and Design (ACCAD) na mesma instituição. Entretanto, comecei a participar das sessões telemáticas do ADaPT: the Association for Dance and Performance Telematic, formada pela Arizona State University, Ohio State University, University of California-Irvine, University of Utah, Florida State University e University of Wisconsin, apresentando ao final a performance DRYWET.

${ }^{4}$ A Rede Ipê é uma rede acadêmica de comunicação gerenciada pela Rede Nacional de Ensino e Pesquisa (RNP) e está equiparada às principais redes avançadas do mundo, como Géant2 (Europa), CaNet*3 (Canadá) e internet2 (EUA).

5 As questões relacionadas à percepção reverberam na performance do dançarino, em como ele atua durante a execução da obra, uma vez que trabalhamos com improvisação e não coreografia (atuação corporal pré-definida). A tomada de decisão do artista em cena é um dos focos de atenção da pesquisa em ambientes telemáticos e mediados tecnologicamente, os quais provocam outras possibilidades de ignição da estratégia composicional do sujeito.
} 
cena, como também aqueles que permaneceram apenas como investigações durante o processo, muitos dos quais não chegam a ser utilizados na obra.

Conforme afirma Cecíla Salles em seu livro sobre a Crítica Genética (2008):

\begin{abstract}
Na medida em que lidamos com os registros que o artista faz ao longo do percurso de construção de sua obra, ou seja, os índices materiais do processo, estamos acompanhando seu trabalho contínuo e, assim, observando que o ato criador é resultado de um processo. Sob essa perspectiva, a obra não é, mas vai se tornando, ao longo de um processo que envolve uma rede complexa de acontecimentos (Salles, 2008, p. 25).
\end{abstract}

Portanto, ao verificar os aspectos recorrentes nas minhas diversas obras, percebo que meus rastros "são a concretização desse processo de contínua metamorfose" (Salles, 2008, p. 25), e isso demonstra a importância do conjunto de processos como um arcabouço de conhecimento adquirido. Coloco em discussão as marcas deixadas no processo genético da minha atividade artística, os memes ${ }^{6}$ que foram replicados nos diversos processos criativos da minha trajetória, de tal forma a perceber a coerência com os projetos de dança telemática que venho desenvolvendo. Um sentido mais próximo ao conceito de semiose do filósofo americano Charles Sanders Peirce (1839 - 1914), uma vez que cada meme, como um signo, a cada processo desdobra-se em novas tríades de distintas naturezas semióticas, mantendo relações de coerência e codependência com o sistema ao qual pertence. Sendo assim, as marcas que reincidiram na minha trajetória artística propiciaram a construção de um conhecimento que, de forma dinâmica, em constante semiose, replicaram-se até alcançar uma outra possibilidade de configuração: a Dança Telemática.

Diante desse olhar processual, uma primeira reflexão é feita sobre a obra entremeios, criada especialmente para a abertura do SESC Santo Amaro em São Paulo em 1998. Esse trabalho serve como um primeiro índice a denotar meus interesses na discussão sobre: espaço, tempo e presença através da dança com mediação tecnológica. A obra foi apresentada em um espaço aberto onde o público presenciava a existência de uma esfera plástica transparente e inflada de três metros de diâmetro e atrás dela havia uma enorme tela de projeção. A esfera abrigava dois dançarinos que, quando se movimentam, locomoviam a

\footnotetext{
${ }^{6}$ Meme foi definido como uma "unidade de replicação cultural" pelo biólogo evolucionista britânico
} Richard Dawkins em seu livro The Selfish Gene, Oxford: Oxford University Press, 1989. 
estrutura. No interior da esfera havia uma micro câmera que captava as imagens dos dançarinos, as quais eram projetadas em direto na enorme tela sobrepostas a outros vídeos pré-gravados as quais mostravam os dançarinos em meio aos escombros da construção do que viria a ser a sede do SESC Santo Amaro. Outra imagem era do avatar que pertencia às animações criadas no software Life Forms $^{7}$ utilizado para construir a coreografia. A proposta de entremeios era mostrar a memória daqueles dois processos: (1) de transformação de uma construção civil para um espaço destinado à cultura e às artes e (2) do desenvolvimento de uma coreografia, da simulação pelo avatar à efetivação em um corpo biológico/cultural. A presença do corpo era multiplicada: (a) no tempo, pois estava presente na performance (tempo presente de um acontecimento) em conjunção com suas imagens no momento da reforma do local (tempo passado pontual) e da elaboração da coreografia digital (tempo passado processual) e (b) no espaço, onde os corpos eram instaurados nos locais de atuação (escombros, dançarinos dentro da esfera, nas imagens), nos contextos da projeção (imagens pré-gravadas, imagens em direto, animações do avatar) e na própria cena que conjugava todos esses elementos.

A obra entremeios estabelecia um confronto da noção de presença do dançarino, pois o corpo físico podia ser visto apenas através da membrana plástica da esfera, enquanto sua imagem direta era observada apenas por meio da micro câmera que captava e projetava os dançarinos no telão. Desta forma, o público podia olhar a esfera e, através dela, os dançarinos, ou poderia tomar como seu ponto de vista o "olho da câmera", a qual podia "ver" os dançarinos sem a interface da esfera. Não apenas o corpo desdobra-se nesse processo de telepresença, como também as noções de interno e externo ficam atravessadas. As explorações dos vários espaços e tempos tornavam-se formas de articulação entre os ambientes do interior da esfera com seu exterior e com sua projeção. A noção de presença começava a ganhar novas compreensões e, assim como o espaço-tempo, continuaria a ser desenvolvida nos processos criativos seguintes.

\footnotetext{
7 O Life Forms fez parte da minha investigação de mestrado, do qual um dos objetivos era compreender a relação da informação corporal processada no avatar e aquela colocada no corpo biológico. A pesquisa de mestrado foi publicada como Corpo Aberto: Cunningham, dança e as novas tecnologias (São Paulo: EDUC, 2002). O Life Forms foi desenvolvido na Simon Fraser University, em 1989, pelo Dr. Thomas Calvert.
} 
Uma das discussões - e crítica - daquela época no campo da dança era o distanciamento que a tecnologia provocaria entre o dançarino e seu próprio corpo, pois, para muitos, perder-se-ia a intimidade com a corporalidade. Entretanto, investigando intensivamente o programa computacional Life Forms na construção das animações coreográficas, comecei a perceber que o contrário era mais do que certo, era necessário. Para construir uma animação de um passo já concebido ou mesmo uma pequena e simples ação como um pliê em primeira posição de pés, por exemplo, era preciso ter uma clara noção do que acontece no corpo humano para, então, poder construir no corpo do avatar. Trata-se do corpo como processador de informação (Hansen, 2006) que torna a imagem embodied. ${ }^{8}$

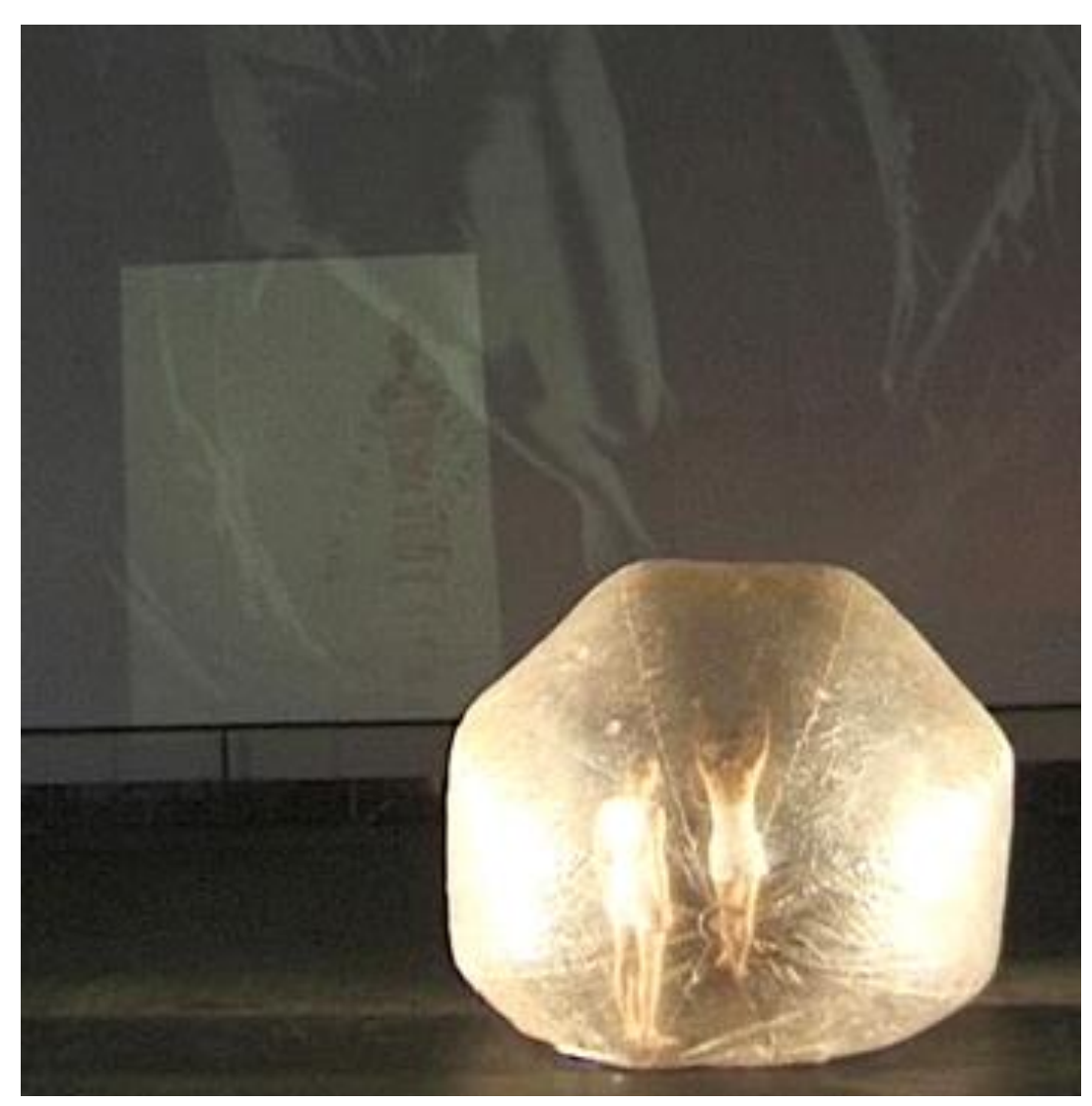

Figura 1 - entremeios (1998), de Ivani Santana. Eram projetadas imagens pré-gravadas do processo criativo e imagens em tempo real capturadas pela micro câmera instalada no interior da esfera.

\footnotetext{
80 termo embodied é referente aos estudos da Embodied Mind Thesis, vertente das Ciências Cognitivas, a qual considera que a natureza da mente humana é formada pelos aspectos do próprio corpo. De acordo com esses estudos, a construção de conceitos, a condição de categorização e a possibilidade de julgamento do ser humano, por exemplo, implicam em como agimos no mundo de acordo com nosso sistema perceptivo e nossas capacidades sensório-motoras. Essa vertente é portanto distinta das linhas do Cognitivismo, Computacionalismo e Dualismo Cartesiano. O termo será utilizado em inglês para evitar compreensões equivocadas com a tradução "encarnada" ou "incorporado".
} 
O solo Corpo Aberto (ver Figura 2 abaixo), selecionado e apresentado no Rumos Dança do Itaú Cultural em 2001, foi totalmente criado através do software Life Forms e as mídias utilizadas em cena. Sendo assim, o trânsito entre os movimentos criados no avatar e a forma como essas ações ficavam quando transpostas para meu corpo estendido pelas tecnologias de imagem eram constantemente intercambiados, ao ponto de não ser possível uma separação ou clareza de qual movimento havia sido criado pelo software e qual era fruto do diálogo com os dispositivos acoplados. O objetivo era mostrar a presença da dança em outros corpos e relatar que não havia interesse em igualar esses corpos, muito pelo contrário.

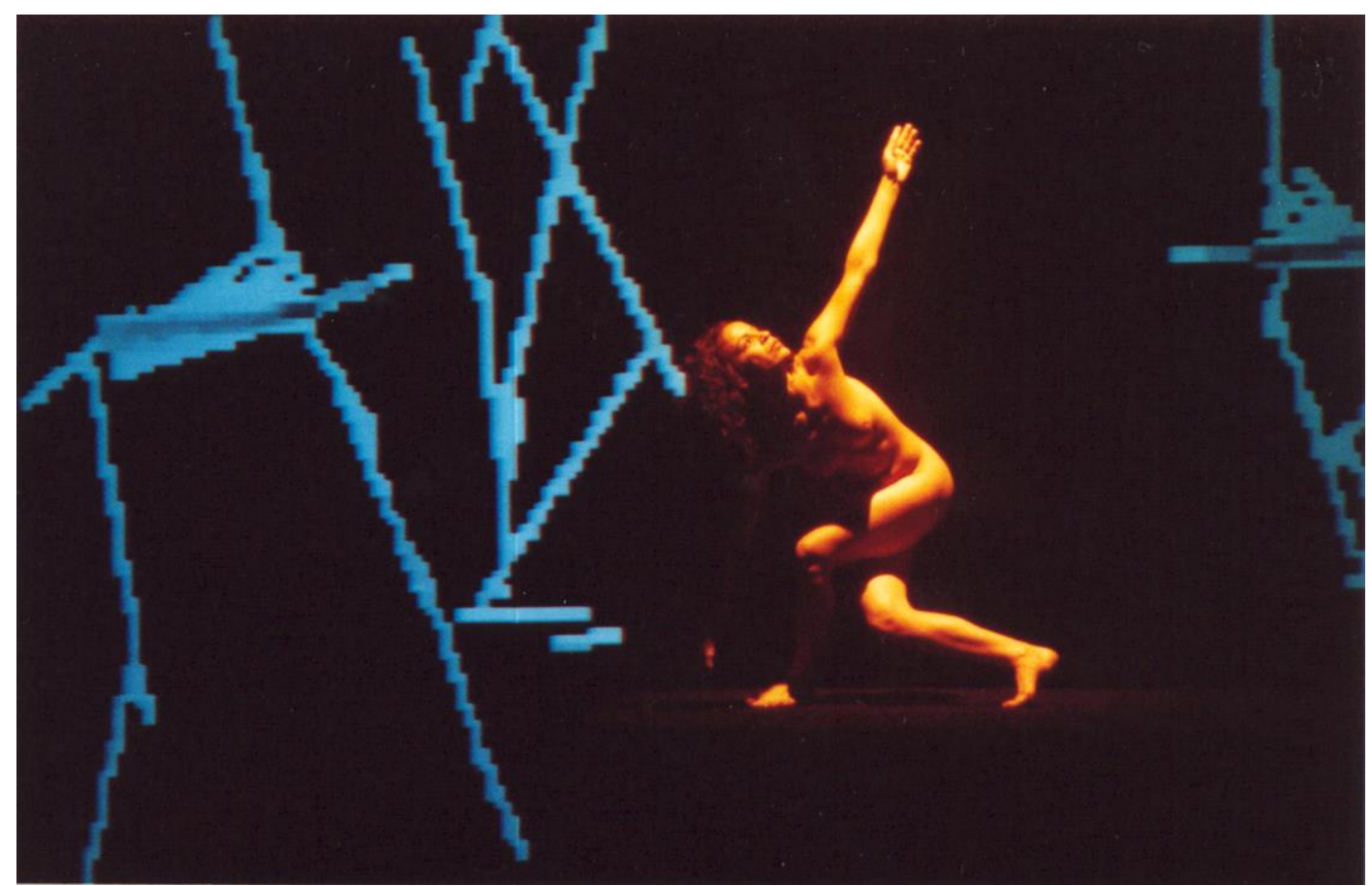

Figura 2 - Corpo Aberto (2001). Bailarina dançando com as imagens do avatar criado no software Life Forms.

Assim como em entremeios (1998), a imagem do avatar foi utilizada em cena, uma forma tanto de levar o processo para o ato performativo, como também para confrontar as duas existências do corpo: o biológico e o sintético (Figuras 3 e 3.1). 

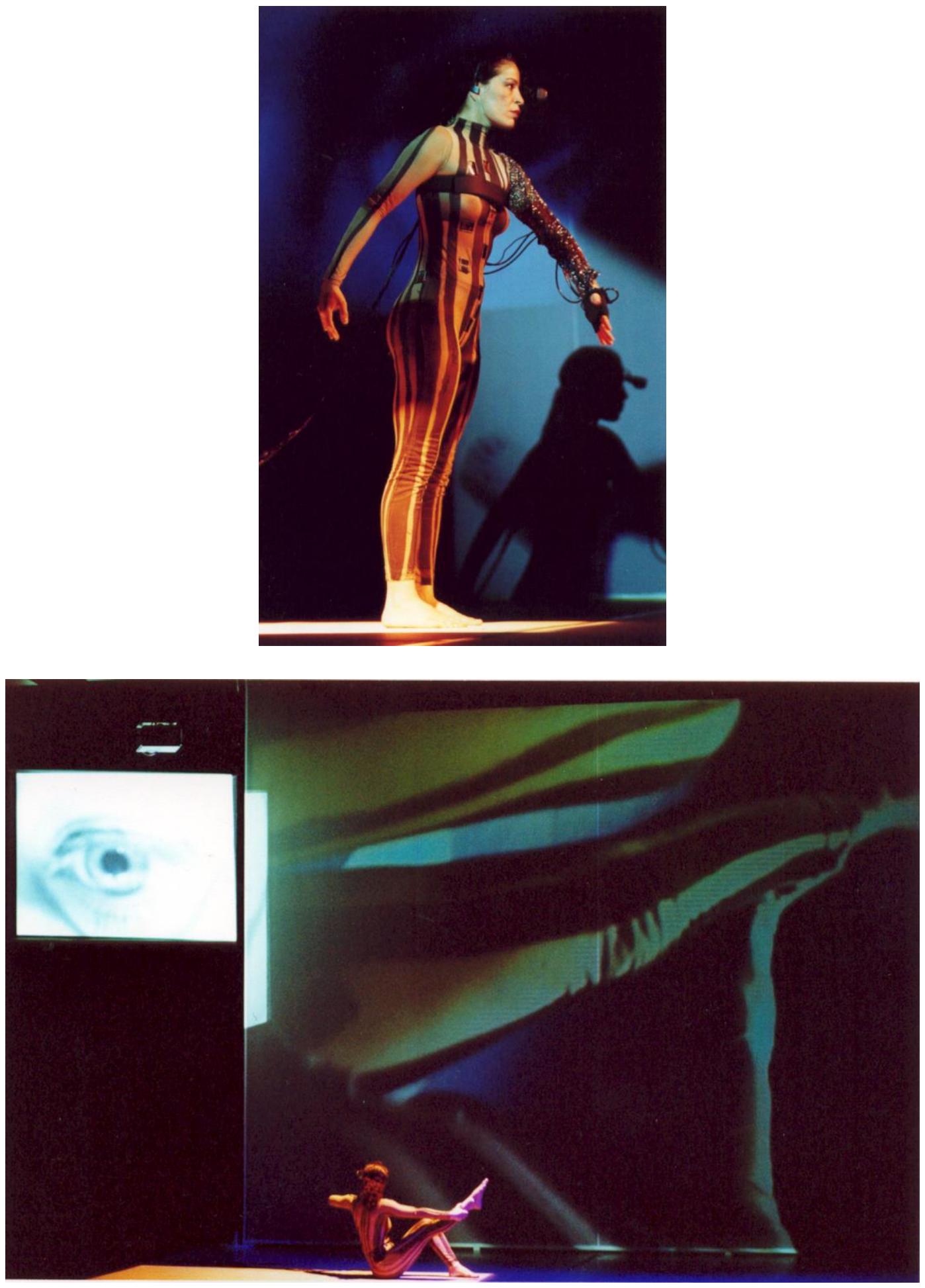

Figura 3 e 3.1 - Corpo Aberto (2001). Micro câmeras foram utilizadas na segunda cena para possibilitar o alcance da visão em pontos imperceptíveis à plateia, como a própria ação do meu globo ocular capturado e projetado durante toda a cena e as imagens de partes do meu corpo ou mesmo ponto de vista do espaço. Em determinado momento da cena, a imagem captada e projetada no telão ao fundo é a própria plateia captada pela micro câmera acoplada à mão da dançarina. 
O espetáculo Corpo Aberto iniciava com o confronto entre o corpo imóvel da fotografia (um momento pré-estabelecido) e a imagem em movimento do corpo atuando em tempo real, questionando a noção de temporalidade (Figura 4). 0 espaço foi distorcido uma vez que o corpo na horizontal era apreciado na verticalidade.

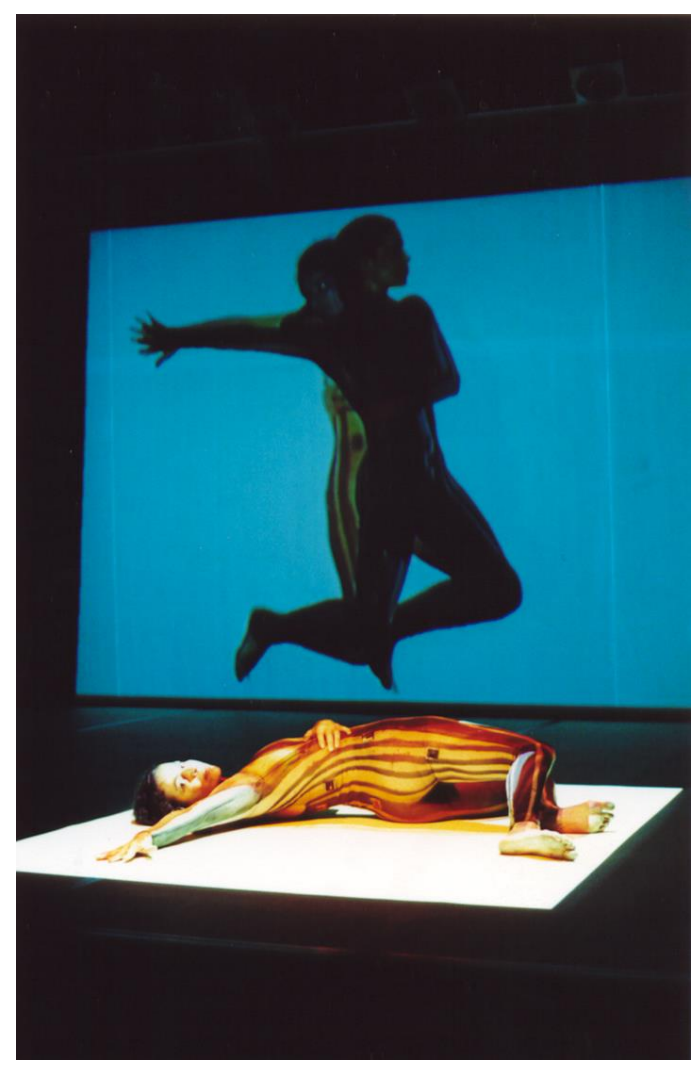

Figura 4 - Corpo Aberto (2001), primeira cena: diálogo entre imobilidade e mobilidade, confronto entre horizontalidade e verticalidade.

A utilização desses dispositivos tecnológicos nas obras citadas são consideradas nesse artigo como artefatos cognitivos que contribuíram para a construção do meu conhecimento na campo da dança com mediação tecnológica, o qual permitiu um efetivo desenvolvimento das minhas pesquisas de Dança Telemática. Compreendendo que a formação dos nossos conceitos e tomadas de decisão estão implicadas em como percebemos e agimos no mundo, pois ocorre um embodiment nesse processo, a constante utilização desses artefatos cognitivos colaboram com a forma como passei a entender e criar dança. Andy Clark afirma, em seu livro Natural-Born Cyborgs, que nós existimos apenas "como coisas pensantes que somos, graças a uma complexa dança de cérebros, corpos e muletas culturais e tecnológicas" (2003, p. 11). 
Em 2002, contemplada no edital do Ateliê de Coreógrafos Brasileiros, realizei a obra Pele ${ }^{9}$ iniciada Estados Unidos com os estudos DRYWET, Study n. 1 - Skyn e, já no Brasil, Estudo n. 2 - organismos, apresentado no FILE - Festival Internacional de Linguagem Eletrônica. Pele tinha o corpo como foco da discussão e levantava questões sobre o que poderia ser chamado de corpo real e qual seria o corpo virtual.

Na abertura da obra, dois dançarinos permaneciam no foyer do Teatro Castro Alves e em frente à Praça do Campo Grande após a entrada do público, enquanto suas imagens eram projetadas no palco, onde um outro duo ocorria simultaneamente. A plateia era confrontada então com esses dois espaços: palco e foyer. A metáfora "dentro e fora" e "interior e exterior" eram intensamente exploradas desde a entrada do público que era obrigado a atravessar uma tela de projeção construída de elásticos transmitindo imagens pré-gravadas dos dançarinos. A primeira cena apresentava uma dançarina em cima da mureta do fosso de orquestra, parte do seu corpo era visível ao público e a outra, a parte oculta era projetada na grande tela na boca de cena. Outra forma para discutir os limites dos sistemas (dentro/fora, interior/exterior) foi preencher a enorme plateia de dois mil lugares com catorze monitores que transmitiam as imagens da Praça Campo Grande ao vivo, provocando a discussão sobre ecossistemas que se sobrepõem num mesmo período de tempo.

Os processos criativos que seguiram já estavam contaminados por essas ideias, um trânsito de conceitos que intercambiavam entre as obras cênicas e aquelas realizadas no campo da telemática, como a instalação performativa Casa de Nina (2004) que utilizava o telefone celular para criar uma rede de relações durante a performance, ou ainda o espetáculo e fez o homem a sua diferença (2005) que priorizava a particularidade do ponto de vista, a individualidade do espectador, tanto pela organização espacial que fazia do espaço como pela forma como os corpos agiam em cena (ver Figura 5). O aspecto imersivo e individualizado

\footnotetext{
9 Uma análise mais detalhada encontra-se no livro Dança na Cultura Digital, de minha autoria (Salvador: EDUFBA, 2006).

Vídeos deste e de outras obras mencionadas no texto podem ser acessadas no link do grupo de pesquisa Poéticas Tecnológicas http://www.poeticatecnologica.ufba.br/site/. Ver também clip inserido como documento suplementar a este artigo.
} 
dessas obras mostravam que um conhecimento ganhava corpo e maturidade na pesquisa da dança articulada com a cultura digital.

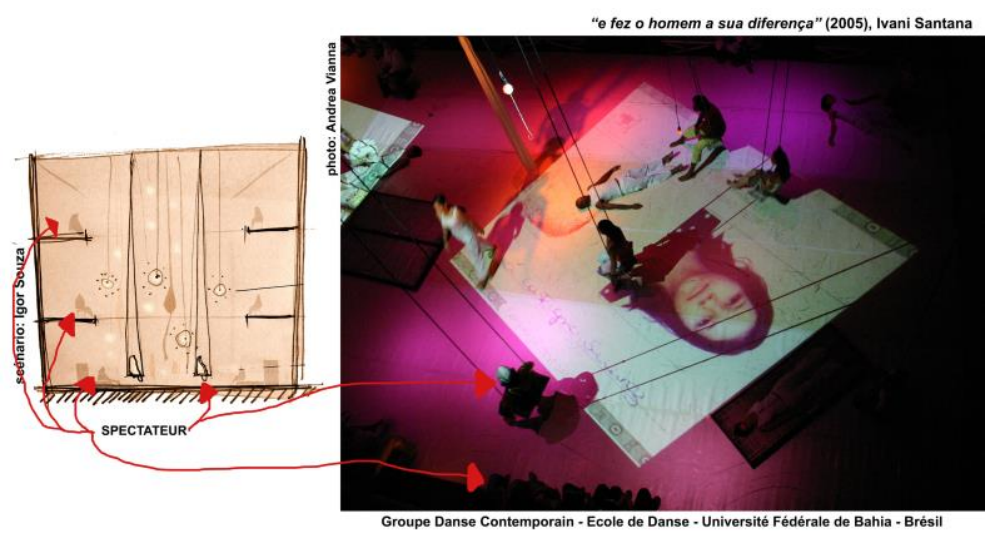

Figura 5 - e fez o homem a sua diferença (2005) e a disposição do público: no "interior" da obra e ao redor em 3 níveis distintos. Cada local possibilitava uma relação diferente com a obra.

A obra Le Moi, le Cristal et L'Eau (2007) criada durante a residência artística ${ }^{10}$ no Centre Coreographique National (França) foi estruturada como uma obra distribuída (Figura 6). 0 palco italiano do Pavillon Noir foi desconstruído e todo o espaço (coxias, palco e plateia) foram utilizados para ambientar vários nichos de atuação tanto dos dançarinos como dos músicos, técnicos, iluminador e até mesmo do público.

10 A residência artística no Centre Coreographique National, dirigido por Angelin Prejlocaj, foi recebida como prêmio no Monaco Dance Forum 2006. 


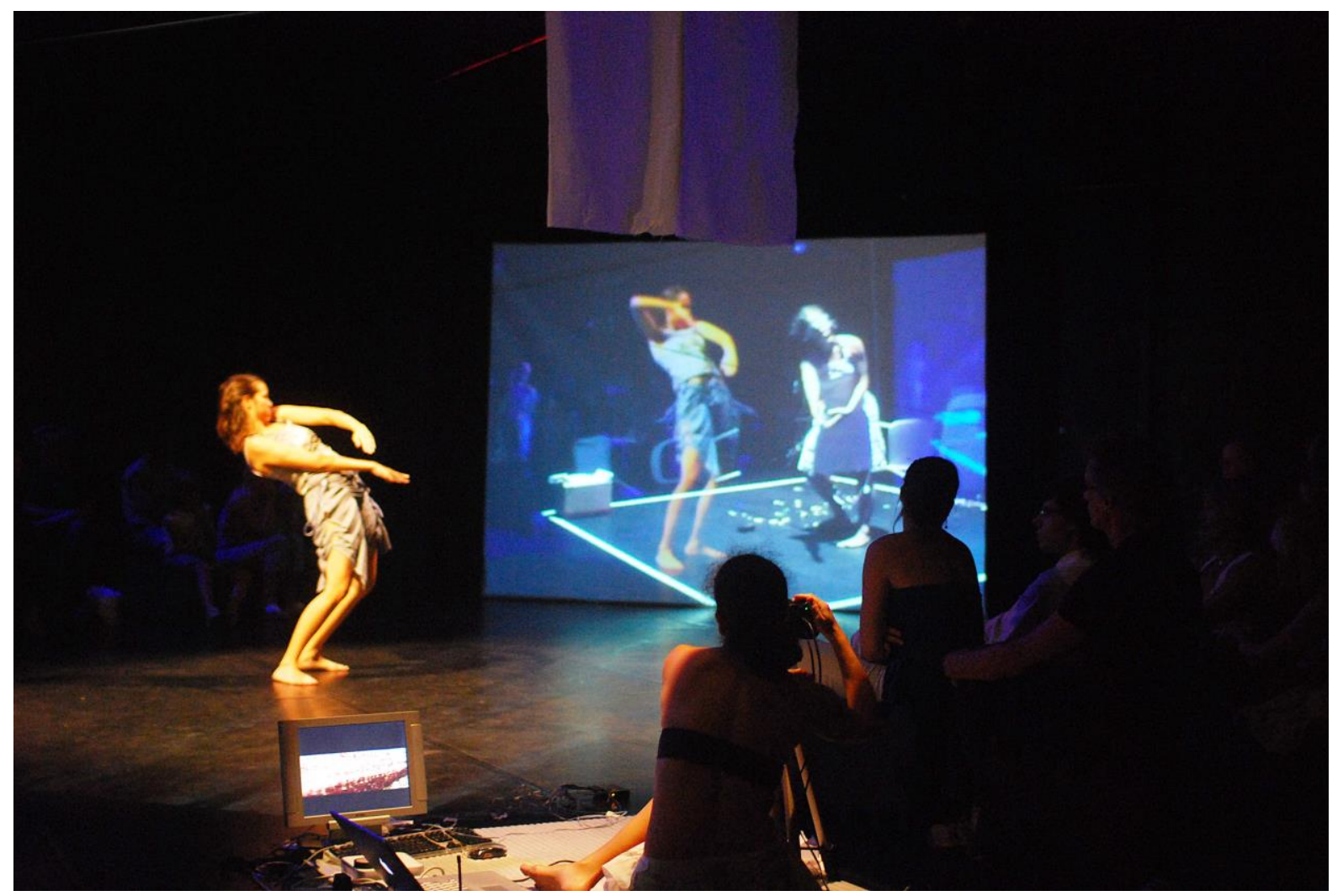

Figura 6 - Le Moi, le Cristal et L'Eau (2007) O princípio da telemática utilizado em ambiente cênico para interligar os nichos de atuação.

O público tinha acesso aos vários acontecimentos de cada micro contexto da obra e, através dos dispositivos de imagem, criávamos pontos de conexão. A produção de conhecimento na dança telemática passava a criar novas demandas para as produções cênicas e vice-versa.

Ao observar e analisar o percurso construído desde a década de 1990, é possível verificar que minhas pesquisas sempre questionaram as noções de presença, espaço, tempo e percepção humana. O uso da internet, nem de qualquer outro dispositivo tecnológico, foi utilizado apenas como gerador de efeitos, mas como um artefato cognitivo que tem expandido as formas como tenho produzido e refletido sobre Arte.

Versus (2005) foi minha primeira criação em dança telemática e contou com o suporte técnico do CPD/UFBA, do LAVID/UFPB e da RNP. A obra foi realizada em tempo real entre três cidades brasileiras: Salvador e Brasília com dançarinos, e João Pessoa. Essa foi a primeira obra de dança telemática realizada no Brasil por meio de redes avançadas. As imagens foram captadas e projetas em altíssima 
resolução e com uma latência mínima. As imagens dos parceiros remotos muitas vezes eram transmitidas depois de serem processadas pelo software Isadora ${ }^{11}$. $\mathrm{O}$ aspecto digitalizado, redimensionado e alterado da imagem do corpo era um dos pontos fortes de discussão do trabalho. Conforme aponta Hansen:

\begin{abstract}
A realidade codificada em um banco de dado digital pode muito facilmente ser apresentada como um arquivo de som, uma imagem estática, um videoclipe, ou um mundo imersivo e interativo, sem mencionar outras formas que não são tão adaptadas as nossas capacidades sensoriais. Visto dessa forma, a era digital e o próprio fenômeno da digitalização podem ser entendidos como demarcando uma mudança na correlação dos dois termos cruciais: mídia e corpo. Colocando de forma simples, como a mídia perde as especificidades materiais, o corpo toma uma função proeminente como um processador seletivo da informação. (...) é o corpo - o escopo de possibilidades perceptivas e afetivas do corpo - que informam as interfaces da mídia (Hansen, 2006, p. 22).
\end{abstract}

Para Hansen, a imagem é embodied pois depende da nossa fruição para se dar a ver. É através do nosso aparato perceptivo que a imagem codificada pelo processamento é transformada, por isso somos um "processador seletivo da informação". Justamente esse deslocamento e proeminência do corpo nesse processo que faz as novas mídias serem "novas" segundo Hansen.

Um dos objetivos nos processos criativos que tenho realizado na telemática é justamente explorar essas possibilidades de codificação pela mídia que a digitaliza e de decodificação pelo sujeito que a frui, seja ele o dançarino que interage com seu parceiro redimensionado e processado digitalmente, seja o público que absorve a relação entre corpos imagéticos e físicos. Até o ano de 2012 foram realizados mais de dez trabalhos com parceiros nacionais e internacionais investigando diversas formas de conexão com diferentes abordagens e de artefatos tecnológicos e cognitivos.

No âmbito internacional podemos citar o convite para participar do Proyecto Paso, da coreógrafa espanhola Salud Lopes, diretora do grupo en lugar de criación. Na versão de 2006, essa obra foi realizada entre Sevilha (Espanha), Arizona (Estados Unidos da América) e Salvador (Brasil) e apresentada na Bienal Internacional de Artes de Sevilha. Diferente da minha preocupação em conectar

\footnotetext{
${ }^{11}$ Software Isadora foi criado por Marc Coniglio, fundador do grupo americano Troika Ranch.
} 
corpos distantes, para Lopes o interesse estava apenas na simultaneidade das ações, não havia interesse na articulação efetiva entre os corpos.

Outro destaque internacional é a parceria estabelecida com a Fundación i2Cat e o Konic Thtr, de Barcelona, com a qual foram criadas três versões do espetáculo e_Pormundos Afeto. Essa obra telemática é fruto do Grupo de Mídias Digitais e Artes - GTMDA - (2009/2010), financiado pela RNP, realizado em parceria com o LAVID/UFPB. O GTMDA foi responsável pelo desenvolvimento da ferramenta Arthron que gerencia o fluxo de informação entre os pontos remotos participantes. As funções principais e a arquitetura do Arthron foram baseados na experiência obtida com Versus (2005), a qual foi criada a partir dos conhecimentos adquiridos com meus processos criativos anteriores em dança com mediação tecnológica. Fruto de um projeto interdisciplinar, o Arthron não foi simplesmente uma execução de engenheiros que escreveram linhas de códigos de programação para elaborar mais um aplicativo para transmissão de imagens. Ao contrário, justamente pelo Arthron carregar um conhecimento adquirido na trajetória artística discutida nesse artigo, conquistou um diferencial entre os demais aplicativos do gênero, posto que a maioria deles possui o áudio como foco e não a imagem. A competência do LAVID em transmissão de vídeo com alta resolução encontrou no conhecimento artístico que venho desenvolvendo durante todas essas décadas a chave para a construção desse dispositivo. Vale ressaltar que no ano de 2011, a pesquisadora Tatiana Aires levou a ferramenta para a telemedicina e uma outra versão começou a ser desenvolvida para esses fins. Esse é um exemplo que reafirma a importância de trabalhos interdisciplinares e o valor do conhecimento produzido pelas Artes. Meus processos criativos em Dança Telemática têm utilizado o Arthron desde a implementação da primeira versão do aplicativo. Essa atitude possibilitou uma ampla e profunda exploração da ferramenta que foi testada em diferentes configurações artísticas, colaborando assim para seu desenvolvimento no campo das Artes.

Outras experiências internacionais foram realizadas como 0 projeto Ecotelemedia $^{12}$ (2011) e o consórcio com a Ásia na performance Dancing Across

12 O projeto Ecotelemedia foi coordenado pelo professor dinamarquês Kjell Yngve Petersen, realizado entre Copenhagen (Dinamarca), Beijing (China), Washington (EUA), Salvador (Brasil) com meu grupo de pesquisa - e Rio de Janeiro com o artista Guto Nóbrega e utilizou, basicamente, o Facetime e o PureData como ferramentas de conexão. 
Oceans (2012). Esse último utilizou o Arthron como ferramenta para interligar Tailândia, Coréia, Espanha e Brasil. Nossa participação deve-se ao convite que recebi da APAN - The Asia and Pacific Advanced Network - para colaborarmos com o grupo de engenheiros e artistas desses países. Essa experiência foi bastante importante para discutir a questão do tempo, uma vez que contamos com uma enorme diferença de fuso horário entre os países participantes. Foi interessante compartilhar o horário local com os companheiros internacionais, pois percebíamos claramente a sensação da convergência dos vários tempos. A madrugada (Brasil), a manhã (Espanha), o final da tarde (Coréia) e a noite (Tailândia) estavam entrelaçados pela obra. Os mundos de culturas tão distintas redobravam-se, ficavam implicados em um único instante com vários tempos.

Por onde Cruzam Alamedas (2006) teve o caráter mais de estudo do que de espetáculo, apesar de ter sido apresentada em um importante evento na Universidade Federal da Bahia. A performance foi realizada em dois locais de Salvador, contando com dançarinos e músicos em cada ponto. Através dessa performance foi possível verificar a importância do uso de camadas de imagem para construção da dramaturgia, o qual se tornou uma das bases para o desenvolvimento de composição e narrativa dos meus processos de dança telemática.

A dramaturgia foi um dos pontos de investigação do projeto Laboratorium MAPA D2, o qual contou com patrocínio da VivoLab e reuniu sete grupos de pesquisa de quatro cidades brasileiras, sendo quatro para suporte tecnológico e três de diferentes linguagens artísticas, a saber: Ceará com teatro e audiovisual pelo Laboratório de Poéticas Cênicas e Audiovisuais (UFC), Rio de Janeiro com o grupo Arte e Novos Organismos (UFRJ), e em Salvador com meu grupo de pesquisa voltado para a dança, música e interatividade. O resultado desse projeto foi a obra Frágil (2011) apresentada no Museu de Arte Moderna do Rio de Janeiro.

Além da importância de ser um projeto realizado entre diferentes linguagens artísticas, Frágil teve a preocupação de criar a obra também para o público da Internet. Desta forma, idealizei uma plataforma que permitia ao usuário construir sua própria narrativa do trabalho e em tempo real. Todas as câmeras dos três grupos artísticos eram disponibilizadas nessa plataforma permitindo ao usuário escolher o que e como assistir, uma vez que as janelas de imagem poderiam ser alteradas (ampliadas, sobrepostas, lateralizadas na tela, etc.). 
Desta forma, a obra Frágil teve um foco de atenção muito forte tanto na construção das diversas narrativas que se entrecruzavam, como com a forma de fruição, seja ela em um dos espaços de apresentação ou na Internet. Como todas as câmeras poderiam ser escolhidas a qualquer instante pelos usuários da rede, tivemos a necessidade de construir a narrativa de cada dispositivo para os quase 40 minutos de performance.

A narrativa da obra para o usuário da rede tem sido um dos pontos da pesquisa. No espetáculo e_Pormundos Afeto (2009) o público da Internet poderia entrar em um mundo virtual como um avatar e esse ambiente era projetado no palco de Barcelona. Pelo princípio de camadas, nós recebíamos a imagem da dançarina da Espanha à frente da projeção do mundo virtual com os usuários e criávamos a composição final da obra. Portanto, a narrativa incluía dançarinos e público virtual.

As experiências vivenciadas durante esse percurso de criação da Dança em Rede alcançaram alguns resultados sobre as questões relacionadas ao "como fazer" e sobre "para quem, ou mesmo por quem é feita". Vale ressaltar que a competência, dimensão e acessibilidade das tecnologias de telecomunicação foram transformadas drasticamente durante esse período de experimentação, alterando e impulsionando assim as experiências artísticas a cada novo invento. Desta forma, abaixo são colocadas apenas algumas considerações adquiridas nos processos criativos realizados. Apesar de não serem conclusivas, elas significam, ainda assim, uma produção de conhecimento substancial que venho desenvolvendo no campo da dança com mediação tecnológica e, desde 2005, especificamente em pesquisas focadas na investigação do corpo telemático.

O "como" dessas performances de dança, ou seja, suas configurações, significa construir um ambiente múltiplo ou, talvez, de forma mais precisa: trata-se de uma obra que mostra suas várias faces, seus vários lados. A ideia de construir um espaço único para os corpos remotos é um entendimento simplista, romântico e redutivo da arte em rede. O que faz dessa configuração um "meio" interessante é aproximar os pontos diferentes - aproveitando-se justamente das suas singularidades para efetivá-los e realizá-los mutuamente. Maquiá-los em um suposto "mesmo espaço" (desejado por muitos que a abrigam num "ciberespaço" homogêneo) é descartar a alteridade, a presença do outro "vindo" de longe e de um outro tempo (ex.: latência, fuso horário). O espaço é uma 
amálgama por simulacro, enquanto o tempo é uma convergência inexorável da realidade telemática. A composição da Dança em Rede apresenta em cada ponto remoto os diferentes pontos de vista desse espaço amalgamado como nos mundos invertidos de Versus (2005), e que ocorre num mesmo instante de tempo que pode sobrepor manhã, tarde e noite com no caso do Dancing Across Oceans (2012).

Essas obras são realizadas para a cooperação de corpos distantes, remotos "de quem faz" interessados em provocar e em receber novos estímulos sensoriais, com desejo de propiciar outras possibilidades perceptivas, como atuar com as várias camadas imagéticas de Por onde Cruzam Alamedas (2006) ou mesmo interagir com um corpo remoto projetado na própria pele como em (In)TOQue (2008). Trata-se da compreensão do dançarino como um "corpo processador seletivo de informação" (Hansen, 2006) que permite a interação em um sistema latente com sua presença e de seu parceiro remoto a partir da imagem digital embodied do corpo. Tal diálogo promove uma ação corporal adaptada ao atraso da informação (delay), seja alterando a dinâmica corporal para contemplá-lo, ou seja, deixando-o imperceptível aquele que assiste (portanto negando-o), ou de forma contrária, aproveitando o delay, utilizando a defasagem do tempo como o próprio objetivo estético (sendo assim, aceitando a latência).

Minhas experiências no campo da Dança em Rede são fruto de uma produção de conhecimento que foi fomentada desde a década de 1990 quando iniciei meu processo criativo em dança com mediação tecnológica. É importante também pensar que essa pesquisa artística apenas pôde ocorrer pela minha vinculação tanto no mercado cultural como na instituição acadêmica.

A Arte em Rede expõe as possibilidades perceptivas para compreender outras noções (talvez novas) de presença, distância, espaço e tempo. A Dança Telemática como um artefato cognitivo deve ser maturada no nosso nicho cultural de forma a apreendermos seus potenciais e, então, conseguirmos processar essas novas informações. É uma questão de tempo! 


\section{Referências}

BAUMGÄRTEL, Tilman. Immaterial Material: Physicality, Corporality, and Dematerialization in Telecommunication Artworks. In: At a Distance: Precursors to Art and Activism on the Internet. Cambridge: MIT Press, 2005, p. 60-70.

Disponível em: http://www.lee-web.net/pdfs/389/MATERIAL.pdf. Acesso em: 02 mai. 2014.

CLARK, Andy. Natural born-cyborg. Oxford: Oxford University Press, 2003.

DAWKINS, Richard. The Selfish Gene. Oxford: University Press, 1976.

DAWKINS, Richard. O rio que saía do Éden: uma visão darwiniana da vida. Rio de Janeiro: Rocco, 1996.

FLUSSER, Vilém. Agrupación o conexión? In: GIANNETII, Claudia (Ed.). Ars telematica. Telecomunicación, Internet y Ciberespacio. Barcelona: ACC L'Angelot, 1998.

HANSEN, Mark. New philosophy for new media. Cambridge: MIT Press, 2006.

KOZEL, Susan. Closer: performance, technologies, phenomenology. Cambridge: MIT Press, 2006.

PEIRCE, Charles S. Semiótica. São Paulo: Perspectiva, 2000.

PRADO, Gilbertto. Arte telemática: dos intercâmbios pontuais aos ambientes virtuais multiusuário. São Paulo: Itaú Cultural, 2003. Disponível em:

http://poeticasdigitais.files.wordpress.com/2009/09/2003-

arte telematica dos intercambios pontuais aos.pdf. Acesso em: 02 mai. 2014.

SALLES, Cecília. Crítica genética: fundamentos dos estudos genéticos sobre o processo de criação artística. São Paulo: EDUC, 2008.

SCHROEDER, Franziska; REBELO, Pedro. Sounding the Network: The Body as Disturbant. Leonardo Eletronic Almanac. V. 16, Issue 4-5, p. 1-10, 2009.

Disponível em:

http://www.leonardo.info/LEA/DispersiveAnatomies/DA schroeder-rebelo.pdf. Acesso em: 02 mai. 2014. 